\title{
Multiculturalism, Interculturalism, Transculturalism and The Reluctant Fundamentalist ${ }^{1}$
}

\author{
JOSÉ MANUEL ESTÉVEZ-SAÁ
}

University of A Coruña, Spain

\begin{abstract}
The most influential theorists of multiculturalism and interculturalism have attempted a rigorous re-examination of their proposals, as demonstrated by recent publications such as "Interculturalism versus multiculturalism -The Cantle-Modood debate" (2015) and Multiculturalism and Interculturalism: Debating the Dividing Lines (2016). Both Ted Cantle and Tariq Modood have acknowledged the need to revise the concepts of interculturalism and multiculturalism as a response to the rapidly changing circumstances of contemporary societies. This paper seeks to: briefly review recent assessments of interculturalism and multiculturalism; attempt to establish a dialogue between the interculturalism-multiculturalism debate and the precept of transculturalism (Dagnino 2012, McLeod 2011); and exemplify the usefulness of the transcultural approach in the exegesis of literary fictions such as Mohsin Hamid's The Reluctant Fundamentalist (2007), a novel that because it operates at the level of both multicultural and intercultural encounters is able to richly contribute to these debates and discourses. The paper argues for the salience of critical terms such as "transnational writer", "transnational literature", "transculturality" and "transculturalism" as they offer a critical vocabulary particularly appropriate for the study of the movements and migrations of people that are depicted with increasing regularity in twenty-first century literature in English.
\end{abstract}

Keywords: Multiculturalism, interculturalism, transculturalism, contemporary literature in English, Mohsin Hamid, The Reluctant Fundamentalist

Many changes and inevitable readjustments have taken place in Western societies (specifically the UK and the USA) since they began to be considered exponents of multiculturalism in the 1960s. The most profound and radical of these have taken place after the 9/11terrorist attacks, and these revisions to multicultural and intercultural relationships answer to the new and varying economic circumstances as well as to political conflicts that have led both Europe and America to rethink their migration policies.

As a consequence, the most influential theorists of multiculturalism and interculturalism have deployed an honest and rigorous attempt to conceptually re-examine their proposals, as reflected in the recent publications of "Interculturalism versus Multiculturalism -The Cantle-Modood Debate" (2015) and Multiculturalism and Interculturalism: Debating the Dividing Lines (2016). Both Ted Cantle and Tariq Modood have acknowledged importance of the need to revise interculturalism and multiculturalism as a response to the new and changing circumstances of contemporary societies.

These circumstances include, among others, the different dynamics of migration that Nikos Papastergiadis describes in The Turbulence of Migration, where he emphasises the relevance and looming presence of the term "migrant" and warns us about the dangers of "hostile stereotyping" (51). Papastergiadis vindicates "a broader understanding of the spatial and gendered forms of migration" as a "necessary precondition for understanding the dynamics of migration in contemporary social relations" (53). This would necessarily convey a series of distinctions and questions, which reflected in Mohsin Hamid's The Reluctant Fundamentalist, as this paper will argue, will have to take into account the following considerations: 
Is economic survival at the centre of migration, or is the journey the first step in the pursuit of a personal dream of cultural progress? Do migrants leave home out of necessity or do they head out for new opportunities? These questions of geography and cultural transformation problematise the distinction between voluntary and involuntary movement. For if economics is not the only factor that stimulates migration, then the sociological literature on migration must also be read in conjunction with the debates in the disciplines of politics, cultural studies and psychology. (Papastergiadis 57)

Emigration and immigration are recurrent topics of discussion in the Western world. This has been so, at least, from the nineteenth century if not before. Nevertheless, we tend to continue to think, speak and write about the topic in restricted terms, despite the experience accumulated over centuries. Therefore, immigrants are taken for granted in affluent countries during periods of wellbeing, and considered a problem at times of economic crisis. Similarly, emigration is regarded as a sign of cosmopolitanism when people move freely from one country to another, but viewed as a tragic experience when economic or political motifs force human beings to abandon their native places. Politics and economy seem to be decisive factors when dealing with these issues so much so that politicians tend to forget that it is human beings who are involved in their speeches.

The financial circumstances and the political affiliation of immigrants and emigrants are undeniably important, but we should also take into account the importance of, at least, their historical, linguistic and cultural backgrounds. There is a tendency to forget that not everyone emigrates for economic or political reasons, and that there can also be affective, professional, and even spiritual motifs involved, as evidenced in The Reluctant Fundamentalist. Moreover, as Papastergiadis suggests, "any current definition of the migrant must also address a complex array of sexual, political, economic and cultural forms" (58). It is these forms that are foregrounded by Hamid in The Reluctant Fundamentalist.

Within the context provided by these new social circumstances and varying dynamics of contemporary human exchanges, it is my intention to briefly review recent assessments of interculturalism and multiculturalism. I do this to try to establish a dialogue between the interculturalism-multiculturalism debate and the precept of transculturalism. Additionally, I attempt to exemplify the usefulness of the transcultural approach in the exegesis of literary fictions such as Hamid's novel, a work that operates at the level of both multicultural and intercultural encounters and discourses. Marco Antonsich, when introducing the CantleModood debate, observes that since contemporary societies are becoming increasingly diverse, the question is no longer how to live together with, but in diversity (Antonsich 2), and Cantle and Modood in their defence of interculturalism and multiculturalism respectively attempt to vindicate the validity of each of their approaches to the challenge posed by Antonsich.

Cantle seems to dismiss multiculturalism as belonging to an era long past, i.e. the 1960s and 1970s, a moment when minorities in society first became visible. According to him, multicultural policies have failed as they have been unable to adapt to the new dynamics of diversity. Although he rejects the need for a new "brand", he acknowledges that interculturalism should be developed "as a completely different concept which reflects the new realities of diversity" (Antonsich 3, emphasis mine). Cantle emphasises that the intercultural approach recognizes the changing and ever-evolving nature of society and of diversity itself, with the latter viewed as a positive dimension of contemporary societies. He further argues for the importance to acknowledge commonality in inter-personal and inter-communal relationships beyond race and ethnic identities.

Nasar Meer and Modood show how central the notions of dialogue and communication are to multiculturalism by revising foundational texts and authors (2011). Modood elaborates that interculturalism is part of multiculturalism, welcoming the contribution of the former to the larger project of the latter. Thus, 
Modood applauds how interculturalists have been able to express, among others, "the importance of intergroup contact and cohesion, not merely multicultural co-existence", "the importance of valuing national citizenship", and "the recognition of the multiplication of the 'multi' and the fluidity, complexity and internal diversity of the identities at the centre of multiculturalism" (Meer and Modood 17). Modood is attempting to establish at the theoretical level the necessary contact and dialogue that interculturalists claim is vital for the understanding of our societies but that they do not put into practice at a theoretical level when they discard multiculturalism as being outdated.

I would relate this debate to another one that is more frequently evoked in literary criticism - the ongoing quarrel between postcolonial and cosmopolitan stances. Without equating the terms, although on many occasions we can find them used interchangeably in the literature on the topic (Keval 2014), the purported emphasis by multiculturalism on the rights of minorities and the need for social policies that guarantee those rights can be considered the result of or an example of postcolonial vindications; and the interculturalists' integrationalist model echoes cosmopolitan stances without convincingly specifying the appropriate mechanisms that would favour co-existence, dialogue and cohesion at the level of the "contact zones", as defined by Marie Louise Pratt (1991). Thus, as it has been stated, interculturalism runs the risk of becoming merely a new narrative, an alternative rhetoric, a novel political myth (Kymlicka 2016).

It is precisely to bridge the gap between multiculturalism and interculturalism that one should turn to the transcultural approach. Rather than tracing its theoretical basis to the works of pioneering figures in the field such as Ortiz, Epstein or Welsch, I focus on recent revisions and elaborations proposed by, among others, Arianna Dagnino (2012) and John McLeod (2011). Supporters of transculturality, transculturalism and transcultural studies argue for the need to remove borders (national, political and mental) and to look for a new approach to contemporary human exchanges that pays attention both to commonality and differences (Epstein, McLeod, Dagnino). From this perspective, the cultural background of people is clearly privileged over economic or political factors. This resonates with the position of Papastergiadis, as mentioned earlier, who considers economic issues as too restrictive and therefore inadequate for comprehending contemporary experiences of migration. Transculturalism is, consequently, a perspective that incorporates the legacy of postcolonialism and cosmopolitanism, but tries to avoid postcolonialism's emphasis on difference and cosmopolitanism's blind faith in commonality. Transculturalism maintains that attention to and care about human exchanges should take into account successful cultural interchanges as well as consider and accept the silences, misunderstandings, gaps and failures that can also take place (McLeod 11).

Transculturalism thus emerges as an efficient theoretical stance to deal with the various forms of cultural interactions and transactions taking place all over the world. The transcultural method focuses on the negotiations that are established between difference and commonality, as well as between cultural communication and social silence. It even establishes a dialogue with the oversimplifications of interculturalism and multiculturalism, and the mistakes that are committed when placing the emphasis on postcolonial or cosmopolitan stances separately.

Therefore, transculturalism incorporates the legacies of postcolonialism and cosmopolitanism, multiculturalism and interculturalism, and exemplifies, when applied to the study of contemporary literature, the need to pay attention to "the incommensurability and singularity" of "non-coincident "contact zones" where critics and readers detect how "representation is anxiously arrested" (McLeod 12). Contemporary literature in English has already begun addressing the need to undertake the necessary revisions to our understanding of multicultural societies and intercultural relationships. The changes in Western communities after September 11, aggravated by subsequent economic world crises, have been recorded in a handful of fictional narratives that question multicultural policies and point to the difficulties of intercultural exchanges. This new scenario has been more urgently and explicitly addressed by South Asian writers, since they have realised that their communities were the ones most directly affected by the aftermath of September 11, 
especially in the form of the mistrust and suspicion levelled at them in the Western societies of their adoption. Along with Hamid's The Reluctant Fundamentalist (2007), Monica Ali's Brick Lane (2003), H.M. Naqvi's Home Boy (2010) and Tabish Khair's How To Fight Islamist Terror from the Missionary Position (2012) have offered fictional instances about the difficulties of intercultural exchange in contemporary multicultural societies.

The analysis I propose of Hamid's The Reluctant Fundamentalist examines how, rather than simply criticising multiculturalism or naively celebrating intercultural dialogue, the novel assumes a transcultural stance that embraces difference and commonality, silence and dialogue as an inevitable aspect of contemporary sociocultural relationships and exchanges.

In The Reluctant Fundamentalist, America is portrayed as a multicultural society in which young Pakistanis like Changez, the protagonist, are able to, culturally speaking at least, feel almost at home:

And that was one of the reasons why for me moving to New York felt -so unexpectedly- like coming home. But there were other reasons as well: the fact that Urdu was spoken by taxicab drivers; the presence, only two blocks from my East Village apartment, of a samosa- and channa-serving establishment called the Pk-Punjab Deli; the coincidence of crossing Fifth Avenue during a parade and hearing, from loudspeakers mounted on the South Asian Gay and Lesbian Association float, a song to which I had danced at my cousin's wedding. (36-37)

It is even overtly stated that young immigrants could benefit from multicultural policies: "Students like me were given visas and scholarships, complete financial aid, mind you, and invited into the ranks of meritocracy. In return, we were expected to contribute our talents to [American] society, the society we were joining" (4-5). Thus, Changez is given a place to study at Princeton, becomes a member of the most fashionable clubs at the university, and is even employed at the prestigious valuation firm Underwood Samson \& Company.

The novel illustrates how Changez does not have to renounce his cultural and social roots, how he preserves his native traditions and mores, even taking advantage of his cultural and ethnic affiliations when he considers it expedient, as, for example, when he visits his American girlfriend's parents:

In the end, I took advantage of the ethnic exception clause that is written into every code of etiquette and wore a starched white kurta of delicately worked cotton over a pair of jeans.

It was a testament to the open-mindedness and - that overused word cosmopolitan nature of New York in those days that I felt completely comfortable on the subway in this attire. (55)

The novel thus reproduces and exemplifies a multicultural New York in which minority groups can preserve their rights as well as flaunt their distinctiveness. Despite Changez's annoyance at some Western mores and habits (including the condescending attitude of the privileged towards the lower classes, or the lack of deference for the old or their elders), the young man's relationship with the young American woman, Erica, suggests that the couple engage with genuine attempts at more than mere multicultural coexistence. In fact, an intercultural dialogue is established between them, as is reflected by the young woman's taking an active interest in Changez's past and family history, his language and the eating and drinking habits of his native community. Changez's story deploys both the young man's preservation of his ethnic identity in multicultural America, as well as the discovery of intercultural commonalities at the level of the contact zones (Pratt 1991), as represented by the firm for which he works:

Two of my five colleagues were women; Wainwright and I were non-white. We were marvelously diverse... and yet we were not $[\ldots]$ 
It struck me then -no, I must be honest, it strikes me now-that shorn of hair and dressed in battle fatigues, we would have been virtually indistinguishable. (42-

The discovery and assumption of intercultural commonalities is also reflected, for instance, in the close relationship that is established between Jim - the young man's supervisor in the firm - and Changez, since both recognise the relevance of belonging to the same class as something that unites them despite their very different origins: "In this, Jim and I were indeed similar: he had grown up outside the candy store, and I had grown up on its threshold as its door was being shut" (81).

Changez is free to move from preserving and even vindicating his ethnic roots to opting for cultural assimilation whenever it suits him as he does when sent to Manila by his firm and he imitates and reproduces precisely the American ways he had previously rejected as impolite and even rude by his ethnic standards:

I did something in Manila I had never done before: I attempted to act and speak, as much as my dignity would permit, more like an American.

$[\ldots]$

So I learned to tell executives my father's age, "I need it now"; I learned to cut to

the front of lines with an extraterritorial smile; and I learned to answer, when asked where I was from, that I was from New York. (74)

The multicultural coexistence and intercultural dialogue experienced by Changez is rudely interrupted by the September 11 terrorist attacks. The young man suddenly discovers his world falling apart; he no longer feels at ease in the multicultural society he lives in and has benefitted from. His efforts at intercultural communication become fruitless. Significantly enough, this is not a revelation that comes from the outside, but from the inner recesses of himself, from the very moment he finds himself smiling at the tragedy he is witnessing unfolding on the television: "I realised that it was not fiction but news. I stared as one - and the other - of the twin towers of New York's World Trade Center collapsed. And then I smiled. Yes, despicable as it may sound, my initial reaction was to be remarkably pleased" (82-83). Changez soon realises that his American dream is on the verge of destruction when multicultural and intercultural exchanges are threatened by the fear and suspiciousness provoked by terrorism:

I ignored as best I could the rumors I overhead at the Pak-Punjab Deli: Pakistani cabdrivers were being beaten to within an inch of their lives; the FBI was raiding mosques, shops, and even people's houses; Muslim men were disappearing, perhaps into shadowy detention centers for questioning or worse. I reasoned that these stories were mostly untrue; the few with some basis in fact were almost certainly being exaggerated; and besides, those rare cases of abuse that regrettably did transpire were unlikely ever to affect me because such things in America as in all countries, happen to the hapless poor, not to Princeton graduates earning eighty thousand dollars a year. (107-108)

From that moment onwards, Changez grows a beard, consciously aware of the suspicion he raises among friends and colleagues, and finally decides to resign from his job and return to Pakistan where he becomes a university lecturer as well as an anti-American activist.

It is significant that Changez's story is framed as a dramatic monologue that takes place in Pakistan, where an older Changez tells of his experiences as an immigrant in America to an unnamed American traveller in transit he has just met at a tea shop in Lahore. It is through this conversation that we learn about Changez's ambivalence as an immigrant in America and this parallels the American man's increasing discomfort in Pakistan. What we know about the mysterious American tourist is deduced from Changez's own words, which describe the Westerner's reactions and prejudices: “Ah, I see I have alarmed you. Do not be frightened by my beard" (1); "It seems an obvious thing to say, but you should not imagine that we Pakistanis are all potential 
terrorists, just as we should not imagine that you Americans are all undercover assassins" (208-209). These two quotations reproduce the beginning and the ending of the novel, and they perfectly illustrate one of the main premises of a text that dwells on the complex relationships between the East and the West.

Neither Changez nor the mysterious American is the stereotypical migrant. As we have seen, Changez went to America to pursue his studies and he then became a successful businessman in the area of high finance. He even fell in love with an upper-class American girl, symbolically named Erica, [Am]Erica. We do not know for certain the reasons for the American man's visit to Pakistan. In fact, this mysterious figure could be a simple tourist, or a member of the American secret police. In any case, the important point is that the novel consciously avoids the stereotypes about migration and migrants that Papastergiadis cautioned us about earlier. Notwithstanding this, the condition of both Changez and the mysterious American as migrants is mainly affected by politics despite the novel's emphasis on the importance of culture.

One of the main lessons taught by transcultural studies and reflected in Hamid's novel is that representing the sexual, political, economic and cultural values implied or embedded in the experiences and exchanges of migration is not always an easy or successful enterprise. It is precisely through a transcultural approach that we can grasp many of the ambivalent stances the reader detects in Hamid's The Reluctant Fundamentalist. The narrative peculiarities of the novel favour the representation of, at least, two clear instances of transcultural exchange. The dramatic monologue that frames the text offers the first example since from Changez's words we discover the attempt at communication and cultural interchange that is taking place between him and the unnamed American. Changez tells him his story, and we can deduce the other man's interest ("you are curious, you say, and desire me to continue? Very well” [82]). Not only does Changez tell him about his years as an immigrant in America, but he also tries to earnestly engage the silent man in Pakistan's traditions, habits, values, food preferences, and so on.

Be that as it may, the account of Changez's experience in North America offers a second example of the complexities of transcultural exchange. He explains how he progressively succeeded in the American scene, first with university friends, and then in his job in the corporate world of finance There are many instances of the implicit barriers that were established between him and his American peers. Changez, for instance, acknowledges his friendship with members of an elitist American university club. He states that he "was well-liked as an exotic acquaintance by some of the others" (19).

Particular attention is paid to linguistic differences. He is told that he has a very "sophisticated accent" (9), and Changez realises that this peculiarity has worked in his favour: "I have subsequently wondered why my mannerisms so appealed to my senior colleagues. Perhaps it was my speech: like Pakistan, America is, after all, a former English colony, and it stands to reason, therefore, that an Anglicised accent may in your country continue to be associated with wealth and power, just as it is in mine" (47). ${ }^{2}$ It is precisely in this recognition of the cultural other that the concept of reciprocity emerges as a key condition for the implementation of the transcultural perspective (Benita Parry 77). Initially, the young man retains his Anglicised accent as well as his politeness, a feature signalled by his American girlfriend: "'I don't think', she said finally, 'I've never met someone our age as polite as you. 'Polite?' I said, less than radiant with joy. She smiled. 'I don't mean it that way,' she said. 'Not boring polite. Respectful polite'” (28, emphasis in original). His "native politeness" sensitizes Changez to the differing attitudes of his fellow countrymen and the Americans to those older of age:

I will admit that there were details which annoyed me. The ease with which they parted with money, for example, thinking nothing of the occasional - but not altogether infrequent - meal costing perhaps fifty dollars a head. Or their selfrighteousness in dealing with those whom they had paid for a service. "But you told us," they would say to Greeks twice their age, before insisting things be done their way. (23) 
Nevertheless, as we have already mentioned, Changez will change and arrive at the point where he even imitates Western attitudes that he had once rejected.

What could be interpreted as Changez's passive colonisation is constantly counterbalanced by the transcultural exchanges between the young man and his American friends, and it is particularly detected in his relationship with Erica, a sort of "ability to move freely from one culture's stance to another and back again", an ability which Anne Holden Rønningregards describes as the "core of transculturalism" (3). And from here emerges the concept of "cultural translation" that Papastergiadis defines as "a dynamic interaction within which conceptual boundaries are expanded and residual differences respected" (131), a sort of turn towards the culture of the other rather than a direct translation of the cultural framework of the other into our own cultural parameters, reinforcing thus the adequacy of a mutual transculturation that avoids the exclusionary bias of what Homi Bhabha calls "cultural supremacy" (327).

Changez accepts and respects the upper-class background of his girlfriend, and tries to sincerely understand her psychological trauma after the death of her former boyfriend. Erica, on her part, earnestly tries to learn about Changez's native Pakistan (30-31). She asks about the landscape, family life, sex and sexual relationships amongst youngsters in Pakistan (104), and is even curious about language: "What does your writing look like?" I said, "Urdu is similar to Arabic, but we have more letters." She said, "Show me," and so I did. "It's beautiful," she said, meeting my eyes. "What's it mean?" "This is your name," I replied, "and this, underneath, is mine" (31). Erica's attitude clearly contrasts with her own father's prejudices about a country that he reduces to finances and dismisses as an economy falling apart (62-63), deploying thus the economic paradigm that Papastergiadis mentioned as dangerously prevalent in the hostile stereotyping of migrants.

Therefore, the novel foregrounds instances of efforts to overcome economic and political parameters, and to establish transcultural connections and exchanges that take into account cultural aspects such as clothes, food, language, and traditions. And this is the first step so that migrants are able to bring down the cultural barriers that society imposes upon them in the land of adoption and to "succeed in integrating [...] and thus [being] able to keep their freedom from any of them [cultures involved]" (Epstein 330).

Notwithstanding, the transcultural exchange between Changez and Erica inevitably acknowledges that silence, lack of communication, and differences are not so easily overcome. Their relationship is highly symbolic, since she clearly represents, as I have mentioned, [Am]Erica and, just as the young woman is fixated with Chris her dead lover, the country in the aftermath of the terrorist attacks becomes also nostalgically oriented towards the past. Changez draws parallels between Erica and her native country:

[I]t seemed to me that America, too, was increasingly giving itself over to a dangerous nostalgia at the time. There was something undeniably retro about the flags and uniforms, about generals addressing cameras in war rooms and newspaper headlines featuring such words as duty and honor. I had always thought of America as a nation that looked forward; for the first-time I was struck by its determination to look back. (130-131)

In these circumstances, multicultural coexistence is seriously questioned, and intercultural dialogue radically interrupted. Changez, on discovering his foreignness, begins to look at America and the Americans with new eyes for fear of becoming a janissary, ${ }^{3}$ a traitor to his own country: "I was a modern-day janissary, a servant of the American empire at a time when it was invading a country with a kinship to mine [Afghanistan], and was perhaps even colluding to ensure that my own country faced the threat of war" (173).

Therefore, he decides to abandon both his job and his adoptive country and go back to Pakistan. His position as a university teacher in Pakistan enables him to advocate independence for his country and disengagement from America. 
This state of affairs would lead us to believe that The Reluctant Fundamentalist deploys an inevitably pessimistic view of the relationship between America and the Islamic world, or between West and East. However, the final message of the novel, I argue, is by no means a negative one.

Changez's multicultural experience in the States was certainly disrupted by the terrorist attacks. Notwithstanding, there is a framed narrative in which Changez tells a mysterious American of his experiences long after they have taken place. Time may have passed, but the reader can detect a new effort at a transcultural exchange taking place in a different setting. On this occasion, the location is Lahore, and the migrant in question is the American in Pakistan. Changez takes pains to explain to the unnamed Westerner the ways of his native culture, as seen in their appreciation of food and their hospitality and kindness towards foreigners. Changez is repeating precisely what he had tried to do with Erica when in America, although now less naively, and he accepts and even understands the American man's suspiciousness, reluctance, fear, and above all, silence.

It is true that the American man displays signs of being uneasy, even frightened, and Changez himself is suspicious about the man's intentions in Pakistan. Theirs cannot by any means be considered a smooth, frictionless exchange, but we have already seen how transcultural connections assume commonality and difference, communication and silence. Jeff Lewis has explained that "transculturalism is distinguished, in particular, by its emphasis on the problematic of contemporary culture, most particularly in terms of relationships, meaning-making, and power formation. However, transculturalism is as interested in dissonance, tension, and instability as it is with the stabilising effects of social conjunction, communalism, and organisation" (13). As Changez tells the man, "There are adjustments one must make if one comes here from America; a different way of observing is required" (140). And this advice to the American in Lahore is the fruit of Changez's own experiences in America. He tells the American that one has to "reacclimatise" (141).

What the novel advances is a sort of "suspension of disbelief", the opportunity to let the other speak, and to listen to him/her. Particularly significant is that the American remains silent throughout the conversation. America is symbolically compelled to listen to the other and to learn, for instance, that "we were not always burdened by debt, dependent on foreign aid and handouts; in the stories, we tell of ourselves we were not the crazed and destitute radicals you see on your television channels but rather saints and poets and - yes - conquering kings" (115-116).

The novel ends without leaving clear answers and on a note of uncertainty. This should not necessarily be interpreted as a failure of the transcultural exchange that is taking place, but rather as an inevitable and even desirable dimension of contemporary relationships. It is not clear if Changez has become a fundamentalist or not, or if the American traveller is a spy or a mere tourist. The author himself has had to explain that the name of his protagonist, Changez, is not a variation of "changes" but rather that "it's the Urdu name for Genghis, the Mongol conqueror who attacked the Muslim world. And with this name Changez can't really be a religious fundamentalist" (Reese 1).

Therefore, it is not preconceptions or fixed interpretations that the novel demands from its readers but, as the author himself explicitly expressed in an interview, empathy:

I believe that the world is suffering from a deficit of empathy at the moment. The political positions of both Osama Bin Laden and George W. Bush are founded on failures of empathy, failures of compassion toward people who seem different. By taking readers inside a man who both loves and is angered by America, and by allowing readers to feel what that man feels, I hope to show that the world is more complicated than politicians and newspapers usually make it seem. We need to stop being so confused by the fear we are fed. A shared humanity should unite us with people we are encouraged to think of as our enemies. (Blakenship 1) 
If as readers we are compelled to display a sympathetic attitude towards the characters involved and the events told, it ensues that, as critics, we need a new terminology and a discourse that accounts for contemporary circumstances and updates postcolonial and cosmopolitan legacies. Transculturalism attempts to do precisely this. It has even defined the "transcultural writer" as well as offered a new discourse for dealing with and speaking about contemporary socio-cultural exchanges.

Arianna Dagnino has referred to "transcultural writers" in the following terms: "imaginative writers who, by choice or by life circumstances, experience cultural dislocation, live transnational experiences, cultivate bilingual/pluri-lingual proficiency, physically immerse themselves in multiple cultures/geographies/territories, expose themselves to diversity and nurture plural, flexible identities" (1). Dagnino's definition exemplifies Hamid's vital experience, an experience that he has summarised in an interview on the occasion of the publication of The Reluctant Fundamentalist. When asked about his national affiliation after having grown up in Pakistan, living in the United States first and now settled in England, Hamid responded:

I've realised that it's important to stop trying to think I'm any one thing. People are confused as to their identity and try to cling to one aspect of that identity to describe what they are: American, Republican, Muslim. These are really incomplete. I'm a guy who spent a lot of time in Pakistan, in America, lives in London, likes sushi, writes books. And unlike Changez, I don't want to pick "Muslim" and "Pakistani" and say: "That's it". I want to pick the complicated name for what I am and have a calm inner life, rather than pick the simple name and deal with all the tensions of leaving everything else out. (2)

Hamid's stance in refusing to adhere to a monolithic national, political, religious or cultural affiliation has materialised in a text whose discourse dramatises transcultural procedures.

Ultimately, The Reluctant Fundamentalist is not a naïve portrait of the relationships between the East and the West. It gives voice to a protagonist from the East even though we detect the interactions and exchanges between Eastern and Western characters. These exchanges are mainly represented through the lens of culture and simultaneously include communicative attempts and silences and even misunderstandings. Significantly, the novel is also a self-conscious reflection on the possibilities and limits of cross-cultural connections.

In all these ways, the novel exemplifies very well the redoubtable, self-reflexive and self-critical stance of transculturalism (Lewis 16). Changez assumes various cultural stances - as an exotic other in multicultural America, as a successful and fully-integrated American, and as an anti-American fundamentalist in defense of his native homeland. He is a compelling and complex character who exemplifies the inevitably provisional nature of intercultural exchanges and transactions that are always contingent on negotiation, revision, criticism and readjustment.

The Reluctant Fundamentalist offers a perfect fictional representation of what Bhikhu Parekh calls a "multiculturally sensitive interculturalism" and "an interculturally attuned multiculturalism" (279). Furthermore, Parekh acknowledges that "every culturally diverse society needs to make its own choice between these two and possibly other forms in the light of its history and circumstances" (279, emphasis added). Hamid's representation of the changing historical circumstances of both America and Pakistan in the aftermath of September 11 advocates transculturalism as an alternative trope with the potential to build bridges between multiculturalism and interculturalism in ways that acknowledge the cultural complexities in and with which we must learn to live. 


\section{NOTES}

${ }^{1}$ This research is part of the project entitled "New Typologies of European (E/Im) Migration and their Representation in Twenty-First Century Literature in English" (FFI2012-38790), funded by the Spanish Ministry of Economy and Competitiveness.

${ }^{2}$ This linguistic awareness is detected also in Changez's exchanges with the American: "Observe, sir: bats have begun to appear in the air above this square. Creepy, you say? What a delightfully American expression - one I have not heard in many years!” (71). Language is certainly taken into account as a key factor in transcultural exchanges in the novel.

${ }^{3}$ The novel reminds us who the janissaries were: "“They were Christian boys [...] captured by the Ottomans and trained to be soldiers in a Muslim army, at that time the greatest army in the world. They were ferocious and utterly loyal: they had fought to erase their own civilizations, so they had nothing else to turn to" (172).

\section{WORKS CITED}

Antonsich, Marco "Interculturalism versus multiculturalism-The Cantle-Modood debate". Ethnicities, 2015, pp.1-24. DOI: 10.1177/1468796815604558.

Bhabha, Homi. The Location of Culture. Routledge, 1994.

Blankenship, Michelle. "Harcourt Interview with Mohsin Hamid”. Mohsinhamid.com, Mar. 2007, http://www.harcourtbooks.com/reluctant_fundamentalist/interview.asp

Dagnino, Arianna. "Transcultural Writers and Transcultural Literature in the Age of Global Modernity." Transnational Literature, vol. 4, no.2, 2012, pp: 1-14.

Dawson, Ashley. "Cargo Culture: Literature in an Age of Mass Displacement." WSQ: Women's Studies Quarterly, vol. 38, no.1 \& 2, 2010, pp: 178-193.

Epstein, Mikhail N. "Transculture: A Broad Way between Globalism and Multiculturalism". American Journal of Economics and Sociology, vol. 68, no.1, 2009, pp: 327-351.

Hamid, Moshin. The Reluctant Fundamentalist. Penguin Books, 2008.

Keval, Harshad. 'From 'Multiculturalism' to 'Interculturalism' -A commentary on the Impact of De-racing and De-classing the Debate". New Diversities, vol. 16, no.2, 2014, pp: 125-139.

Kymlicka, Will. "Defending Diversity in an Era of Populism: Multiculturalism and Interculturalism

Compared." Multiculturalism and Interculturalism: Debating the Dividing Lines, edited by Nasar Meer, Tariq Modood and Ricard Zapata-Barrero, Edinburgh UP, 2016, pp. 158-177.

Lewis, Jeff. "From Culturalism to Transculturalism”. Iowa Journal of Cultural Studies, vol.1, 2002, pp: 123.

McLeod, John. "Sounding Silence: Transculturation and Its Thresholds". Transnational Literature, vol.4, no.1, 2011, pp: 1-13.

Meer Nasar and Tariq Moodod. "How does Interculturalism Contrast with Multiculturalism?” Journal of Intercultural Studies, 2011, pp:1-22.

Meer, Nasar, Tariq Modood, and Ricard Zapata-Barrero, editors. Multiculturalism and Interculturalism: Debating the Dividing Lines. Edinburgh UP, 2016.

Papasterrgiadis, Nikos. The Turbulence of Migration. Globalization, Deterritorialization and Hybridity. Polity Press, 2000.

Parekh, Bhikhu. Afterword: Multiculturalism and Interculturalism -A Critical Dialogue". In Nasar Meer, Tariq Modood and Ricard Zapata-Barrero, editors. Multiculturalism and Interculturalism: Debating the Dividing Lines. Edinburgh UP, 2016, pp. 266-279.

Parry, Benita. "Directions and Dead Ends in Postcolonial studies". In Relocating Postcolonialism, edited by 
David Theo Golberg and Ato Quayson, Blackwell, 2002, pp. 66-81.

Pratt, Mary Louise. “Arts of the Contact Zone.” Profession 91, 1991, pp. 33-40.

Reese, Jennifer. "Reluctant's Success”. EW.Com. Entertainment Weekly. 13 June. 2007, http://www.ew.com/ew/article/0,20042152,00.html

Rønning, Anne Holden. "Literary Transculturations and Modernity: Some Reflections." Transnational Literature, vol. 4, no.1, 2011, pp: 1-10. 